\title{
The Importance of local party activity in understanding Canadian politics: Winning from the ground up in the 2015 federal election - CORRIGENDUM
}

William Cross

DOI: https://doi.org/10.1017/S0008423916000962, Published by Cambridge University Press, 4 November 2016.

Some of the data reported by Cross (2016) on page 615 of the original article were incorrect. The correct data are as follows: 62 per cent of associations with a woman president had a woman contest the nomination compared to 49 per cent with a man as president.

In associations with a male dominated executive, 49 per cent had a woman contest the nomination compared to 57 per cent with gender balance on the executive.

Finally, the presence of a local search committee increases the likelihood of a woman contesting the nomination by 10 per cent.

The corrections, which have no effect on the conclusions drawn, result from a combination of coding error and additional information becoming available from Elections Canada.

The author regrets the error.

\section{Reference}

Cross, William. 2016. "The Importance of local party activity in understanding Canadian politics: Winning from the ground up in the 2015 federal election." Canadian Journal of Political Science / Revue canadienne de science politique 49 (4): 601-620. https://doi.org/10.1017/S0008423916000962

\footnotetext{
Cite this article: Cross W (2019). The Importance of local party activity in understanding Canadian politics: Winning from the ground up in the 2015 federal election - CORRIGENDUM. Canadian Journal of Political Science 52, 629. https://doi.org/10.1017/S0008423919000684

(C) Canadian Political Science Association (l'Association canadienne de science politique) and/et la Société québécoise de science politique 2019
} 